\title{
"I Would Have Become Wallpaper Had Racism Had Its Way": Black Female Professors, Racial Battle Fatigue, and Strategies for Surviving Higher Education
}

\section{Nicola Rollock}

To cite this article: Nicola Rollock (2021) "I Would Have Become Wallpaper Had Racism Had Its Way": Black Female Professors, Racial Battle Fatigue, and Strategies for Surviving Higher Education, Peabody Journal of Education, 96:2, 206-217, DOI: 10.1080/0161956X.2021.1905361

To link to this article: https://doi.org/10.1080/0161956X.2021.1905361

ช (c) 2021 The Author(s). Published with license by Taylor \& Francis Group, LLC.

Submit your article to this journal $\square$

View related articles $\sqsubset$

Citing articles: 1 View citing articles $\square$
Published online: 06 May 2021.

凹 Article views: 728

View Crossmark data \ulcorner 


\title{
"I Would Have Become Wallpaper Had Racism Had Its Way": Black Female Professors, Racial Battle Fatigue, and Strategies for Surviving Higher Education
}

\author{
Nicola Rollock \\ University of Cambridge, Cambridge
}

\begin{abstract}
In 2019, AdvanceHE reported that there were just 25 UK Black female full professors in British universities. Black women are less likely to occupy a role at this level than their male and White counterparts. Despite this, Black women remain relatively absent in institutional initiatives to advance gender equality, and there is little commitment amongst UK universities to explicitly address structural inequalities of race as they affect the experiences of academic staff. Black female academics remain under-represented and invisible in UK higher education. This article draws on the first known qualitative study into the career experiences and strategies of twenty of these Black female professors. Specifically, it engages Critical Race Theory and Bourdieu as principal theoretical frameworks to explore how their academic journeys, shaped as they are by an existence at the intersection of race and gender, result in racial battle fatigue, feelings of isolation, and disillusion with the academy. The article demonstrates how, despite these challenges, these women have been agentic in their efforts to navigate higher education. They have developed and continue to deploy sophisticated strategies of analysis, hyper-surveillance, selfcare, and resilience in order to carve out a successful career in the academy and remain within it.
\end{abstract}

\section{Introduction}

The topic of race has gained increasing attention in UK universities since the introduction, in autumn 2018, of a deadline set by the Office for Students (OfS) - the independent regulator of student success in higher education-requiring all institutions to eliminate the degree attainment gap by 2024-2025. The objective is to: "eliminate the unexplained gap in degree outcomes ( 1 sts or $2: 1 \mathrm{~s}^{1}$ ) between White students and Black ${ }^{2}$ students by 2024-25, and to eliminate the absolute gap (the gap caused by both structural and unexplained factors) by 2030-31" (OfS, 2018, p. 4).

This has led to widespread activity across the sector, with universities seeking to understand how they might "decolonize their curricula" and introduce initiatives centered at (a perceived) understanding of Black students' experiences. However, despite these efforts, I assert that there has been a failure on the part of institutions to recognize the experiences of their Black students within a wider critical frame that acknowledges that their educational journey is broadly synonymous with that faced by Black faculty and professional support staff. In other words, the fact that Black undergraduate students have the lowest continuation rates of all ethnic groups and are least likely to graduate with a first or 2.1 when compared with their peers ought to be read as part of a broader problem of race inequality that is structurally, historically, and systemically located and in which Black faculty also 
continue to be poorly represented at senior levels and have poor experiences. Therefore, following Ladson-Billings and Tate (1995) — both leading proponents of Critical Race Theory-I posit that the UK higher education sector has not recognized the "intellectual salience" (p. 50) of looking "carefully at race as a powerful tool for explaining social inequity" (p. 50). As such, this shapes how matters of race are understood and framed and which solutions are presented to resolve them.

\section{Black and minority ethnic faculty}

Much of the available research on race and UK academics has tended to amalgamate all racially minoritized $^{3}$ groups together. Academics from these backgrounds report feeling marginalized and undervalued and having their experience frequently called into question (Leathwood, Maylor, \& Moreau, 2009; Shilliam, 2015). The gravity of these findings was echoed by a later study carried out by the University and College Union (which represents the interests of staff in further and higher education), which found that almost $70 \%$ of its Black and minority ethnic members working in higher education had been subject to bullying and harassment by colleagues (UCU, 2016). It is perhaps unsurprising then that academics from Black and minority ethnic backgrounds are more likely than their White counterparts to consider leaving UK institutions to take up posts overseas (ECU, 2015). Read from this perspective, higher education institutions in the UK have a race problem that clearly extends beyond students and degree outcome.

\section{Black female professors}

This article takes account of this wider political landscape as it considers findings drawn from a wider study examining the career experiences and strategies of UK Black female full ${ }^{4}$ professors (Rollock, 2019a). Relatively little attention has been paid to this group and how their engagement with higher education has been marked by a particular set of experiences shaped by an existence at the intersection of race and gender (Crenshaw, 2009). Notable exceptions include Maylor (2009) and Rollock (2013), who detail their experiences as Black women in the academy and how this impacts their role as researchers. Similarly, Mirza (2009) has documented Black women's continued desire for education despite the barriers they face. Finally, a recent edited collection by Deborah Gabriel and Shirley Anne Tate (2017) provides a sobering insight into the prevalence of racism in the British academy through a series of autobiographical accounts by women of color at different stages of their career.

The data revealing the number of Black female professors make for an equally somber read. Black women are less likely to be professors than their White and male counterparts. The most recent data published by AdvanceHE-the body responsible for promoting equalities across the UK higher education sector-reveals that, at the time the research was conducted, $15 \%$ (or $12,790^{5}$ ) of White male academics were professors in 2017-18 compared with just $6 \%$ (or 4,340) of their White female colleagues. That is, White men are more than two and a half times more likely to be professors than their female peers. This disproportionality reflects not just White women's disadvantage within the academy but that White men are at a relative advantage and thus privileged. The figures are starker for Black academics. Fewer than 5\% (90) of Black male academics were professors during this same time period compared with a mere $2 \%$ of Black female academics who held posts at this level. That $2 \%$ equates to just 30 Black female professors (i.e. $25 \mathrm{UK}$ and 5 non-UK). Therefore, while Black men are underrepresented in the professoriate compared with their White male colleagues, they are nonetheless more than twice as likely to

\footnotetext{
${ }^{3}$ Commonly referred to as Black and minority ethnic groups in the UK, or by their acronym BME, or more recently (and often contested by mainly marginalized groups), BAME.

${ }^{4}$ When we refer to professors in the UK, it refers to the full professor equivalent in the United States. It does not include those who are professors at the assistant or associate level.

${ }^{5}$ Refers to UK-domiciled and international data.
} 
be professors than Black women. Looking within gender, White women are three times more likely to be professors than their Black female colleagues. It is these data and the starkness of the disproportionality that led to the present research examining the career experiences and strategies of UK Black female professors.

The current article centers on a key theme to emerge from the research findings. It focuses on the ways in which Black female professors work to navigate higher education despite the challenges they face and considers how they attempt to protect themselves from racism and look after their well-being.

\section{Research methodology}

This article draws on the findings of an 18-month study funded by the University and College Union examining the career experiences and strategies of UK Black female professors. The aim was to understand why there are so few Black female professors, their experiences of higher education, and how they navigated these to reach professorship.

Semi-structured qualitative interviews were carried out with 20 UK-domiciled Black female professors during 2018. The focus on UK-domiciled academics is important as their entry into, representation in, and thus experiences of the academy are likely to differ from their international counterparts (Leathwood et al., 2009; UCU, 2012). The questions drew on themes raised in previous research studies about the workplace experiences of racially minoritized groups (Business in the Community, 2015) and the Black British middle classes (Rollock et al., 2014). Theoretically, and in line with previous research carried out by the author (Rollock et al., 2014), the research was informed by Critical Race Theory and Bourdieu. As such, the questions and subsequent analysis sought to explore and give a platform to the potential role of race and racism in shaping respondents' experiences within a predominantly White academic sector, while simultaneously attending to the intersecting role of gender and institutional context (Delgado \& Stefancic, 2000; Gillborn \& Ladson-Billings, 2010; Ladson-Billings \& Tate, 1995). Bourdieu was useful in helping to conceptualize the normative rules and assumptions dictating what is valued in higher education and how respondents can be viewed as actors seeking to negotiate and gain legitimacy within the subfield of their individual institutions and the wider site of the academy (Bourdieu, 1986, 1997).

Potential respondents were invited to take part in the research through invitations posted on email groups such as the Higher Education Race Action Group and the British Black Studies list. Calls for respondents were also made via social media. Respondents were additionally identified via listings cited in the directory of Black and minority ethnic professors produced and published by the Black Female Professors Forum. ${ }^{6}$ Potential respondents who were already known to the researcher were contacted directly and invited to take part.

The invitation email briefly explained the focus of the research and asked for involvement from those who met three key criteria: they were UK-domiciled, were currently in employment at a UK higher education institution as a full professor, and they self-define as Black African, Black Caribbean, or other Black background. Approximately half of the interviews were carried out in person, with the remainder conducted by Skype. Interviews lasted between one and two hours. Each was fully transcribed by a transcriber who had worked with the researcher during previous projects and had signed a confidentiality agreement relating to the handling and disclosure of data. Each interview was then analyzed partly by hand and partly through use of the qualitative software program NVivo to identify broad themes, areas of dissonance, and similarities in experience.

\footnotetext{
${ }^{6}$ This is an online forum set up by Professor lyiola Solanke (a Black female academic) as a way of connecting and highlighting the achievements of racially minoritized female professors: https://blackfemaleprofessorsforum.org (last accessed September 24, 2019).
} 
The principal focus of the study was to explore why there are so few Black female professors at UK higher education institutions. Specifically, the research sought to explore the following three questions:

(1) What are the career pathways of these academics and, specifically, their experience of attaining professorship?

(2) What strategies do Black female professors make use of to support their career advancement?

(3) What advice and guidance are these academics able to offer future generations of Black female professors?

The intention of the research was threefold. First, it sought to lend visibility to the experiences of a group that is underrepresented in higher education and about which little is known. Second, it is interested in highlighting the ways in which progression, recognition, and promotion-currently an opaque area-operate in UK universities. And finally, it sought to expose the barriers restricting Black female academic progression and to reveal the strategies deployed by this group to overcome them.

\section{Findings}

The findings reveal that Black female academics endure an uneven and convoluted pathway to professorship characterized by undermining, bullying, and the challenges of a largely opaque progression process. The full findings are discussed at length elsewhere (Rollock, 2019a). This article centers on two principal themes to emerge from the data. First, it considers the nature of subjugation and bullying as experienced by the respondents and how, despite this, these women continue to work and devise strategies to navigate these barriers and make significant contributions to their respective fields. Second, in line with Critical Race Theory, it situates these struggles within a wider context of whiteness and white domination (Allen, 2004; Leonardo, 2004). That is, it argues that the strategies and resilience of these women must be understood as contextual and contingent, and as a direct result of the White gendered and racialized norms that underpin UK higher education and enable White men (and women) to progress more readily and occupy decision-making roles.

Given that little is known about Black female professors as a group, the section begins by briefly outlining key demographic information collated during the course of the study.

\section{Who are the UK's Black female professors?}

Of the 20 professors involved in this study, almost half (45\%) had pursued a different career before entering academia. In most cases, their academic specialism was a continuation or extension of what they had done previously. For reasons of confidentiality, it is not possible to give specific examples, but this category would include, for example, someone who previously trained and practiced as a general practitioner (family doctor) and subsequently gave up this role to pursue an academic career in teaching and researching medicine within higher education. The reasons for this career change or for entering academia varied. In some cases, being an academic was seen to offer flexibility for those wanting to raise a family, while other respondents described entering higher education by chance, following, for example, appointment to a short-term teaching contract.

Three respondents were aged between 40 and 49 years at the time of interview, nine were aged between 50 and 59 years, and eight were over 60 years of age. There was no obvious correspondence between age and length of service as a professor. The majority (60\%) of respondents had been appointed professor only within the five years preceding the research, ${ }^{7}$ reflecting the relative newness of those working at this level. However, the findings revealed that this group is in constant flux. During the course of the fieldwork, two respondents mentioned they were either in the process of or had recently initiated legal proceedings against their employer and, since completing the interviews, I have

${ }^{7}$ The interviews were carried out during 2018. 
learned that two further respondents have resigned from their posts. Therefore, while the findings of this study reveal that it takes Black female academics a long time to reach professorship due to the barriers they face en route, it is also the case that the number of Black female professors remains relatively static due to high levels of attrition on account of their poor experiences within the academy.

In the section that follows, I focus attention on the various complex ways in which Black female professors respond to the barriers they face during their careers, endure in their current roles, and continue to demonstrate agency and resilience despite these hindrances.

\section{Strategies for survival}

All 20 respondents shared examples of being on the receiving end of passive or explicit bullying, which ranged from being ignored in meetings to personal verbal abuse and derogatory remarks (Rollock, 2019b). Oade (2015) describes bullying as "behaviours ... designed to cause the target to doubt themselves and experience lowered self-esteem, or cause co-workers to question their competence or commitment." As the name indicates, passive bullying refers to subtle acts such as making derogatory or offhand comments with a smile, excluding a colleague from social events, or undermining a colleague by spreading false rumors about them. Given its subtlety, passive bullying can be hard to identify and to address, and therefore it usually goes unchecked by line managers (Oade, 2015). Further, the fact that individual acts may seem relatively innocuous can result in the victim secondguessing why they feel that they have been the subject of attack. There is an important connection to be made between passive bullying and racial microaggressions. The term racial microaggressions was coined by the African American psychiatrist Chester Pierce in the early 1970s to describe the "offensive mechanisms used by the collective White society ... [to] keep [every Black person] psychologically accepting of the[ir] disenfranchised state" (Pierce, 1970, p. 472). The concept was further developed by psychologists to refer to what they identify as ostensibly slight but persistent putdowns that serve to alienate and denigrate people of color because of their racialized identity (Sue, Capodilupo, \& Holder, 2008):

Racial microaggressions are the brief and everyday slights, insults, indignities and denigrating messages sent to people of color by well-intentioned White people who are unaware of the hidden messages being communicated. These messages may be sent verbally ("You speak good English."), nonverbally (clutching one's purse more tightly) or environmentally (symbols like the confederate flag or using American Indian mascots). (Sue, 2010)

Significantly, the majority of professors in this study were able to point not just to a single act but to a succession of acts of passive bullying (and indeed overt ones) and racial microaggressions that comprised a natural and unremarkable element of their academic journey and that persisted into their current role as professors. In most cases, they were also able to document how they managed these incidents and worked to survive higher education. A good example is evidenced in the interview I carried out with Germaine. Germaine has been a professor for six to 10 years and has a salary at the higher end of the pay band captured as part of the research. In the extract that follows, she describes her experience of attending a meeting not long after starting a new appointment as a professor. The meeting was chaired by a senior White male colleague who mistook her for the new student representative who was also attending the same meeting for the first time:

I can see somebody next to him nudging him to try to explain to him that, no, no ... I'm not the student rep. I'm the new professor. And then the rest of that meeting, which I have prepared for a lot, I have to be careful, because I'm going to have to work with this person for the rest of the time in that institution. I don't want him to have even the slightest sense of hostility from me, so I've got to ... pretend I haven't noticed that he's assumed I'm the student rep or not act in any way offended or put out or anything by that but then overcompensate by being super knowledgeable ... as it happened, we were discussing introducing a new [degree program] ... and I was able to say "Well ... [drawing on my past experience] we did this, and we did that ... and I notice page 17 of the 30 page report suggested this. I would suggest we do this instead." So, by the end of the meeting, he's either forgotten 
about his slip or he's so at ease that it's not [an issue]... I mean, I'm conscious that there are other ways of dealing with it.... I make choices about how I perform in the room.

There are a number of observations to make in relation to this extract. First is the fact that mistaking Germaine for the student representative implies, in a very Bourdieusian sense, that she is not seen to possess or embody the expected characteristics of other academics (actors) who hold the title of professor (Bourdieu, 1997). However, what is of particular interest here is Germaine's reaction, which takes me to my second point. Although we might reasonably assume that being misread in this way might cause some degree of offense, Germaine does not explicitly focus on this. Instead, she centers her attention on forensically managing the situation to protect her colleague with a view to safeguarding against any awkwardness in their relationship and thus hold intact her future career. She seeks to protect her colleague from any potential embarrassment he might feel due to his mistake and, given their different raced and gendered positions, to shield him from any perception that his act might be considered racially naïve or belittling. As such, this example demonstrates a careful project of interpersonal politicking and career management triggered, I argue, by an underlying understanding of the unspoken rules of the racial contract (Mills, 1997) and, relatedly, an understanding of the differential power held by different actors within this social field (Bourdieu, 1997). It is this finely tuned comprehension of these "tacit requirements" (Bourdieu, 1997, p. 103) that leads to Germaine's painstaking concerns about how she presents- "I don't want him to have even the slightest sense of hostility from me"- and to suppress and overlook what her colleague has done by acting as though she has not noticed. However, Germaine's efforts to protect her colleague are not limited to the suppression of her emotions. She further engages in a deliberate enactment of intellectual hypercompetence by going out of her way to share what she knows about the intricacies of degree programming to demonstrate the legitimacy of her place within this academic domain.

This third observation provides an evocative, real-life example of Leonardo and Porter's (2010) argument about the challenges and power dynamics at play between minoritized groups and Whites:

People of color sometimes overlook white violence so they can get through their daily life. Like a child who has been abused, people of color avoid white violence by strategically playing along, a practice that whites, whose racial development stunts their growth, underestimate when they mistake consensus as the absence of coercion. Like abused children who do not possess the ability to consent and defend themselves against the verbal and physical power of a parent, people of color have become masters at deflection. This is how they secure safety in violent circumstances. (2010, p. 151)

As we have established, Germaine was "strategically playing along." She understands that the unspoken provisions of the racial contract require her to protect herself and not expose her White colleague's racial faux pas, which would otherwise out him as racially naïve and complicit in maintaining what we might think of, if we engage Mills's (1997) philosophical theorizing, as the normalized racial disorder of the academy.

Just because race was not explicitly named in this exchange does not mean that race was not present. Indeed, this act or performance of what we might think of as the not seeing of race must be regarded as a characteristic of this very disorder. If we take as our starting point an understanding, as informed by the data, that Black women are under-represented in higher education, then this very fact must serve as the foundation of our thinking and questions and, moreover, shape our actions in any situation where this underrepresented group is featured. Therefore, while perhaps easily dismissed as a relatively innocuous and fleeting moment in the overall meeting, the situation Germaine described in fact exposes how power and violence play out in a covert gendered and racialized way within the structured everyday space and unspoken norms of a meeting and the undue burden this places on her as a woman of color. It is through this lens that we can better comprehend Leonardo and Porter's (2010) discomforting reference to abuse and their related inferences of power and violence. Indeed, Germaine later disclosed how very "exhausting" she finds such incidents, which speaks of not just their physical toll but also of their psychic impact and demonstrates that such acts are, sadly, a normal and unremarkable feature of her academic life (Delgado \& Stefancic, 2000). 
Maureen, based at a different university and slightly older than Germaine, also shared the view that it is necessary to work hard and go beyond the call of duty to prove her academic worth:

You work in your office-and I work hard-and you dedicate yourself to your craft and your students and ... people will find you and you will find people that you can align yourself with ... people that you have some shared values with and those [are] the ones that give you your support.... And one of the things that, well you will know ... you're always constantly proving yourself and having to prove yourself as a female and also as a Black academic, having to show that what you're doing is as good, if not better than what other people are doing. So, you kind of feel that pressure but, in the end, that's how you survive; you get your energy and support elsewhere [outside of the university].

The concept of hard work is evident in both Maureen and Germaine's accounts. However, working hard is not simply an aspect of their role as academics but is also a deliberate act cultivated to circumnavigate the institutional limitations and expectations placed on them as a result of their racialized and gendered positions. In an echo of sentiments also expressed by U.S. faculty of color (Guidry, 2006; Wilson, 2012), merely being good is not seen as enough to warrant the attention and accolades enjoyed by their White peers, and it is knowing this that results in additional effort and pressure to succeed. Further, that this is recognized as a common part of life as a Black woman in higher education is conveyed by the way in which Maureen also implicates me, as a fellow Black female academic, in her analysis.

There is a parallel to be drawn here between Germaine and Maureen's accounts regarding the consequences of this additional labor. Germaine points to her exhaustion, and Maureen highlights the additional pressure she feels, evidencing what the African American scholar William A. Smith (2004) described as "racial battle fatigue":

Racial battle fatigue develops in African Americans and other people of color much like combat fatigue in military personnel, even when they are not under direct (racial) attack. Unlike typical occupational stress, racial battle fatigue is a response to the distressing mental/emotional conditions that result from facing racism daily. (p. 180)

In his 2004 chapter exploring the consequences of working in an environment shaped by race and racism, Smith draws attention to a suite of negative emotional and physiological symptoms of racial battle fatigue, ranging from decreased self-confidence and anxiety to headache, backache, and chronic pain. It is Maureen who disclosed, in lowered but defiant tones, the words that serve as the title for this article- "I would have been wallpaper if racism had its way"-encapsulating vividly the potential physical and mental toll of trying to survive within the academy. She described how she sees many Black female academics "struggling with everyday racism" and the negative impact of this on their mental and physical health. Maureen works to minimize her exposure to this "hostile environment" (Rollock, 2018) by working in her office, aligning herself with others who share her values, and also by seeking support and building alliances outside of the higher education context. There is also an undercurrent of isolation as well as self-protection in Maureen's strategies-"I lock myself in my room." Not only must Black female academics endure the double bind and challenges of sexism and racism within higher education, it is also a depleting and isolating existence. Perhaps the most striking articulation of the effects of racial battle fatigue and efforts to survive it was conveyed by Lorraine. One of the youngest professors to take part in the study, Lorraine was candid in her analysis and in her admission of what she must do to look after her sanity and well-being:

I have a really big separation between my work life and my home life... I'm very good at putting boundaries [in place] and that is self-protection as well and self-care as well as yoga, just looking after yourself. ... I see so many - that's the other thing, so many Black female academics who just burn out either through ... either they're stressed, [or] they're in some sort of employment tribunal case with their employers, cancer, mental ill health.... And I've seen it time and time again ... you can't take on all the battles, you can't, you've got to look after yourself, and that's why I'm very clear to separate my home life and not take on everything.... I've started to go to the gym.... I've had a therapist for [number of] years now. 
In a textbook example showcasing the consequences of racial battle fatigue, Lorraine documents how she has witnessed the decline-either to career or health-of fellow Black female colleagues, which serves as further evidence of why the number of Black female professors is so low. And just as Maureen seeks to safeguard herself from her academic environment by retreating to her office and locking the door, Lorraine exercises a similar survival strategy by establishing a clear boundary between her professional and personal lives and, in a profound but arguably shrewd act of mental health survival, also regularly visiting a therapist.

\section{Exposing "relations of dominance" 8}

My analysis thus far has centered on the ways in which Black female professors seek to carve out strategies to survive and successfully navigate higher education institutions in the UK. Although I might enthusiastically remark upon their resilience and tenacity-and certainly this should not go without note-the fact remains that the burden of this strategizing should not be required simply to forge a successful career in the academy. Debbie McVitty, editor of a popular UK-based online higher education blog, summarizes the perversity of their situation thus:

These sorts of incidents [that Black female professors go through] create an exhausting double bind-to process one's own emotional response so as to avoid being labelled angry or irrational, and to redouble one's efforts to perform to prove oneself worthy of one's position in the teeth of the covert scepticism of one's peers. (McVitty, 2019)

McVitty's observation provides a stark reminder of Fanon's (1967) compelling and sobering treatise about the continuing role of race and racism in shaping the experiences of the Black man (sic) and the pursuant inescapable bind of being "overdetermined from without" (p. 87). Central to Fanon's analysis, and implicit in McVitty's, is the centrality of whiteness in determining the rules that govern and shape the Black experience. Therefore, while we may laud them for their tenacity, the fact remains that these women have been "compelled to fight" (Rollock, 2019a, p. 29) and compelled to "work out strategies for survival given ... the context in which they have found themselves and given their commitment to their subject specialism" (p. 29, emphasis added). Such observations must compel us, in turn, to question the nature of this context or what Apple (2012, p. xxiv) describes as the "relations of dominance" - the institutional norms and expectations that come to dictate which forms of capital are legitimated and deemed acceptable, who makes and enacts such decisions, and who is included and excluded as a result. As Bourdieu (1997) reminds us:

Any legitimate work tends in fact to impose the norms of its own perception and tacitly defines as the only legitimate mode of perception the one which brings into play a certain disposition and a certain competence...

(a)ll agents, whether they like it or not, whether or not they have the means of conforming to them, find themselves objectively measured by those norms. (p. 29)

Bourdieu does not assume legitimacy to be fixed or unproblematic and indeed regards it as a contested enterprise that is given value by dominant actors in the field. It is through this lens that we can better understand one respondent's view that good work is not sufficient to secure promotion because promotions are "always political decisions," even though this is not made evident in the formal promotion criteria. This is what Bourdieu refers to as "secondary characteristics" (1997, p. 102). Indeed, deploying Bourdieu's theoretical framework demands that we revisit McVitty's statement-and by extension, the comments of the Black women in this study-and consider not just their experiences but who might label them as "angry or irrational" and consider to whom they must turn to be assigned worth or legitimacy. In other words, to create a workplace culture that is racially just and that attends to considerations of intersectionality, we must consider who has power 
and who determines the rules of this space. The answer, as reflected by the data, is White men and, though underrepresented in relation to their male counterparts, White women.

Consequently, I propose that Black female academics' strategies for survival are strategies to survive whiteness and the formal and informal acts that shape it:

The term whiteness refers to a collective racial epistemology with a history of violence against people of color.... Whites are the subjects of whiteness, whereas people of color are its objects. All whites benefit from racist actions whether or not they commit them and despite the fact they may work against them. (Leonardo, 2009, p. 111)

This definition assigns necessary regard to the historical context and, crucially, elucidates how Whites-for the purposes of this article White academics-are implicated in maintaining a racial disorder that ultimately works to their advantage, as witnessed, for example, through their disproportionate representation in professorial roles. Like others (Delgado Bernal \& Villalpando, 2002; Shilliam, 2015), I argue that White norms, assumptions, and expectations saturate higher education. This is implied, I suggest, by Constance's statement that "we're all forced to be a particular kind of academic, to produce only a particular kind of knowledge." This knowledge and the rules that uphold it range from decisions about who is admitted and promoted to discussions about curricula content, how it is taught, and by whom. And as evidenced in the examples discussed earlier, whiteness also saturates the tacit rules governing workplace meetings. Power is central to this entire analysis. Whiteness can be conceptualized as the processes that enable White dominance to be maintained. This means that the violence experienced by Black female professors can be regarded as the moment at which power and resistance to that power come into conflict. Here, I am conceptualizing "resistance" in the form of conscious acts but also as mere presence and difference. Therefore, academia becomes more than a mere site of knowledge exchange between academic peers and student learners. It becomes a space in which White dominance-or what critical race theorists call White supremacy (Gillborn, 2006) - is enacted and maintained:

[White supremacy is a] political, economic, and cultural system in which whites overwhelmingly control power and material resources, conscious and unconscious ideas of white superiority and entitlement are widespread, and relations of white dominance and non-white subordination are daily reenacted across a broad array of institutions and social settings. (Ansley, 1997, p. 592)

The best way to make sense of this is to return to the data. In the extract that follows, Rosemary, who has been a professor for over 10 years, explains how she copes with being constantly undermined by her White colleagues:

Well I get pissed off at them but, you know, I mean life is what it is, you know. I live a very privileged life, so if the worse I have to deal with is ... [the rude tone] in people's emails, I can cope with that ... it shouldn't happen ... sometimes it makes me laugh, right. I mean it usually makes me cross for a minute and then you draft the email response that you keep in your draft folder and then two days later you draft the email that you send, which is always conspicuously polite in my case. I work very hard on my communications.... I work very hard on them to manage my mood, but I think colleagues [do not] . . take as much care to manage their mood as they might with a White male [senior leader].

Rosemary, like Maureen earlier, also gives the impression- "life is what it is"-that her experiences are a normal part of her academic journey. She seeks to rationalize and downgrade her negative experiences by positioning them within a wider perspective that takes account of some of the other benefits available to her as an academic and, as shared elsewhere in the interview, in her personal life. She admits to being annoyed by the rudeness of colleagues' emails and manages this by drafting an initial response, saving it, and returning to edit it two days later as a means of ensuring that the tone is correct. It is easy perhaps to argue that such care and self-regulation should be a normal part of workplace behavior; however, I am interested in the fact that such rudeness is permitted in the first place, and how this may be taken up as unacceptable by the institution. Where such monitoring fails, it is then Black female professors who have to work out what they deem as appropriate and humanizing responses to such acts. Note that Rosemary is "conspicuously polite" (emphasis added), indicating a concerted effort in her 
display of courtesy. Similarly, she works "very hard" on her communications and does likewise with her mood, reflecting not just that she, like other respondents, is a "master of deflection" (Leonardo \& Porter, 2010, p. 151) but that she engages in dedicated, purposeful labor to suppress and manage her true feelings. She does not have the same license as her White peers to be rude or indeed to react with anything other than civility to their inappropriate behavior. This point is corroborated by Lorraine when she said that, "as a Black woman in academia, we're all constantly suppressing how we feel." It is also worth noting Rosemary's observation that if she were a senior White man, she would not be on the receiving end of such communications. Emails, like meetings, are a site of power shaped by the dynamics of race and gender where White norms and expectations prevail.

\section{Discussion}

In this article, I have sought to highlight the ways in which Black female professors in the UK are agentic and purposeful in their efforts to navigate higher education and forge a successful career in the academy. Although due regard ought to be paid to these acts of resilience and determination, I propose that they characterize the shameful consequences of racism and the continued failure to address it and that our attention should equally be attuned to the processes that demand such efforts in the first place. I have argued that power in the form of White dominance saturates higher education and prescribes-often tacitly-the rules that govern it. As Armstrong and Wildman (2012) remind us, "Whiteness does more than simply privilege a certain group of people. Whiteness can also diminish people of color when conformance to white norms becomes the measuring stick for incompetence" (p. 240).

Universities, like many public institutions, author equality and diversity statements and express their unrelenting commitment, in job advertisements and elsewhere, to increasing the number of underrepresented groups, especially women, those with disabilities, and those from Black and minority ethnic backgrounds. However, such statements and promises do relatively little to alter the education landscape either in terms of representation or improving the daily experiences of these groups (Ahmed, 2012). Knowing this compelled a group of Student Union sabbatical officers and students, the majority of whom were of color, at Goldsmiths University in London to stage the occupation of an important historical building on their campus and to issue the senior management team with a list of demands aimed at tackling institutional racism (Rawlinson, 2019; Weale, 2019). Their actions resonate with those of other students across a reluctant UK higher education sector who have demanded answers to questions such as "Why is my curriculum White?" and "Why isn't my professor Black?" (Hussain, 2015; Jahi, 2014). In turn, their actions correspond with wider movements across the diaspora aimed at decolonizing universities and the curriculum, which were initiated in South Africa (Matebeni, 2018) and through the "I too am ..." calls inscribed on placards across various U.S. and UK institutions declaring that racially minoritized students are also part of the norm and have the right to be there (Butler, 2014).

So, 400 years following the enslavement of the first Africans in English colonies, the year 2019 offered us a pivotal moment to reflect upon the colonial project and the extent of Black progress and success. Yet, the continued underrepresentation of Black faculty and students and their differential outcomes compared with their White counterparts indicates in no uncertain terms that the legacy of white domination remains a structuring feature of our institutions and thus our lives. We ought not to be satiated by equalities legislation, policies, guidance documents, and promises for change. Instead, we ought to look to the data as a determining benchmark for success and while so doing hold in mind the incisive words of the scholar Derrick Bell (1992) as he reminds us:

The goal of racial equality is, while comforting to many whites, more illusory than real for blacks. For too long we have worked for substantive reform, then settled for weakly worded and poorly enforced legislation, indeterminate judicial decisions, token government positions, even holidays. I repeat. If we are to seek new goals for our struggles, we must first reassess the worth of the racial assumptions on which, without careful thought, we have presumed too much and relied on too long. 


\section{Author bio}

Dr. Nicola Rollock is Distinguished Fellow at the Faculty of Education, University of Cambridge; Senior Adviser on Race and Higher Education to the VC at the University of Cambridge and Specialist Adviser to the Home Affairs' Select Committee's Macpherson: 21 Years On Inquiry. She is also a member of the Wellcome Trust's Anti-racism Expert Group and the British Science Association's Equality, Diversity, and Inclusion Advisory Group.

\section{References}

Ahmed, S. (2012). On being included: Racism and diversity in institutional life. Duke University Press.

Allen, R. (2004). Whiteness and critical pedagogy. Educational Philosophy \& Theory, 36(2), 121-136. doi:10.1111/j.14695812.2004.00056.x

Ansley, F. L. (1997). White supremacy (and what we should do about it). In R. Delgado \& J. Stefancic (Eds.), Critical White studies: Looking behind the mirror (pp. 592-595). Temple University Press.

Apple, M. (2012). Education and power (2nd ed.). Routledge.

Armstrong, M. J., \& Wildman, S. M. (2012). Working across racial lines in a not-so-post-racial world. In G. Gutiérrez y Muhs, Y. F. Niemann, C. G. González, \& A. Harris (Eds.), Presumed incompetent: The intersections of race and class for women in academia (pp. 224-241). Utah State University Press.

Bell, D. (1992). Faces at the bottom of the well: The permanence of racism. Basic Books.

Bourdieu, P. (1986). The forms of capital. In J. G. Richardson (Ed.), Handbook of theory and research for the sociology of education (pp. 241-258). Greenwood Press.

Bourdieu, P. (1997). Distinction: A social critique of the judgement of taste. Routledge.

Business in the Community (BiTC). (2015). Race at work: Executive summary. BiTC.

Butler, B. (2014, March 5). "I too am Harvard": Black students show they belong. The Washington Post. Retrieved from https:/www.washingtonpost.com/blogs/she-the-people/wp/2014/03/05/i-too-am-harvard-black-students-show-they -belong/?noredirect=on\&utm_term=.7ca9ced55563

Crenshaw, K. (2009). Mapping the margins: Intersectionality, identity politics and violence against women of color. In E. Taylor, D. Gillborn, \& G. Ladson-Billings (Eds.), Foundations of critical race theory in education (pp. 213-246). Routledge.

Delgado Bernal, D., \& Villalpando, O. (2002). An apartheid of knowledge in academia: The struggle over "legitimate" knowledge of faculty of colour. Equity \& Excellence in Education, 35(2), 169-180. doi:10.1080/713845282

Delgado, R., \& Stefancic, J. (Eds.). (2000). Critical race theory: The cutting edge (2nd ed.). Temple University Press.

Equality Challenge Unit (ECU). (2015). Academic flight: How to encourage Black and minority ethnic academics to stay in UK higher education. ECU.

Fanon, F. (1967). Black skins, White masks. Vintage Books.

Gabriel, D., \& Tate, S. A. (2017). Inside the ivory tower: Narratives of women of colour surviving and thriving in British academia. Trentham Books.

Gillborn, D. (2006). Rethinking White supremacy: Who counts in “whiteworld”. Ethnicities, 6(3), 318-340. doi:10.1177/ 1468796806068323

Gillborn, D., \& Ladson-Billings, G. (2010). Education and critical race theory. In M. Apple, S. Ball, \& L. Armando Gandin (Eds.), The Routledge international handbook of the sociology of education (pp. 37-47). Routledge.

Guidry, J. J. (2006). Can a brotha' get a break? Teaching on a majority White research campus. In C. A. Stanley (Ed.), Faculty of colour: Teaching in predominantly White colleges and universities (pp. 166-174). Anker Publishing.

Hussain, M. (2015, March 11). Why is my curriculum White? National Union of Students. Retrieved from https://www. nus.org.uk/en/news/why-is-my-curriculum-white/

Jahi, J. (2014, March 21). Why isn't my professor Black? UCL Blogs. Retrieved from https://blogs.ucl.ac.uk/events/2014/ 03/21/whyisntmyprofessorblack/

Ladson-Billings, G., \& Tate, W. (1995). Toward a critical race theory of education. Teachers College Record, 97(1), 47-68.

Leathwood, C., Maylor, U., \& Moreau, M.-P. (2009). The experience of Black and minority ethnic staff working in higher education. Equality Challenge Unit.

Leonardo, Z. (2004). The color of supremacy: Beyond the discourse of 'white privilege'. Educational Philosophy \& Theory, 36(2), 137-152. doi:10.1111/j.1469-5812.2004.00057.x

Leonardo, Z. (2009). Race, whiteness and education. London, UK: Routledge.

Leonardo, Z., \& Porter, R. K. (2010). Pedagogy of fear: Toward a Fanonian theory of "safety" in race dialogue. Race, Ethnicity \& Education, 13(2), 139-157. doi:10.1080/13613324.2010.482898

Matebeni, Z. (2018, February 19). \#Rhodesmustfall-it was never just about a statue. Heinreich Böll Stiftung. Retrieved from https://za.boell.org/2018/02/19/rhodesmustfall-it-was-never-just-about-statue

Maylor, U. (2009). Is it because I'm Black? A Black female research experience. Race, Ethnicity \& Education, 12(1), 53-64. doi:10.1080/13613320802650949 
McVitty, D. (2019, February 6). We all need to take responsibility for racial inequalities in higher education. WonkHE. Retrieved from https://wonkhe.com/blogs/we-all-need-to-take-responsibility-for-racial-inequalities-in-highereducation/

Mills, C. (1997). The racial contract. Cornell University Press.

Mirza, H. (2009). Race, gender and educational desire: Why Black women succeed and fail. Routledge.

Oade, A. (2015). Active and passive aggression in workplace bullying. Life Labs Psychologies. Retrieved from https:// lifelabs.psychologies.co.uk/users/6695-aryanne-oade/posts/3730-recognising-active-and-passive-aggression-inworkplace-bullying

Office for Students (OfS). (2018). A new approach to regulating access and participation in English higher education. OfS. Retrieved from https://www.officeforstudents.org.uk/media/546d1a52-5ba7-4d70-8ce7-c7a936aa3997/ofs2018_53.pdf

Pierce, C. (1970). Black psychiatry one year after Miami. Journal of the National Medical Association, 62(6), 471-473.

Rawlinson, K. (2019, July 29). Anti-racism activists end Goldsmiths occupation. The Guardian. Retrieved from https:// www.theguardian.com/education/2019/jul/29/anti-racism-activists-end-goldsmiths-occupation

Rollock, N. (2013). A political investment: Revisiting race and racism in the research process. Discourse: Studies in the Cultural Politics of Education, 34(4), 492-509. doi:10.1080/01596306.2013.822617

Rollock, N. (2018, May). A hostile environment? British Sociological Association. Retrieved from https://www.britsoc.co. uk/about/latest-news/2018/may/a-hostile-environment/

Rollock, N. (2019a). Staying power: The career experiences and strategies of UK Black female professors. University \& College Union.

Rollock, N. (2019b, February 6). We urgently need more Black female professors in UK universities. Vogue. Retrieved from https://www.vogue.co.uk/article/black-female-professors-uk-universities .

Rollock, N., Gillborn, D., Vincent, C., \& Ball, S. (2014). The colour of class: The educational strategies of the Black middle classes. Routledge.

Shilliam, R. (2015). Black academia: The doors have been opened but the architecture remains the same. In C. Alexander \& J. Arday (Eds.), Aiming higher: Race, inequality and diversity in the academy (pp. 32-34). Runnymede Trust.

Smith, W. A. (2004). Black faculty coping with racial battle fatigue: The campus racial climate in a post-civil rights era. In D. Cleveland (Ed.), A long way to go: Conversations about race by African American faculty and graduate students (pp. 171-190). Peter Lang.

Sue, D. (2010, October 5). Racial microaggressions in everyday life: Is subtle bias harmless? Psychology Today. Retrieved from https://www.psychologytoday.com/gb/blog/microaggressions-in-everyday-life/201010/racial-microaggressions -in-everyday-life

Sue, D. W., Capodilupo, C. M., \& Holder, A. M. B. (2008). Racial microaggressions in the life experience of Black Americans. Professional Psychology, Research and Practice, 39(3), 329-336. doi:10.1037/0735-7028.39.3.329

Universities and College Union (UCU). (2012). The position of women and BME staff in professorial roles in UK HEIs. UCU. Retrieved from https://www.ucu.org.uk/media/5559/Report-The-position-of-women-and-BME-staff-in-professorialroles-in-UK-HEIs/pdf/The_position_of_women_and_BME_staff_in_professorial_roles_in_UK_HEIs.pdf

Universities and College Union (UCU). (2016). The experiences of Black and minority ethnic staff in further and higher education. UCU.

Weale, S. (2019, March 20). Students occupy Goldsmiths in protest at institutional racism. The Guardian. Retrieved from https://www.theguardian.com/education/2019/mar/20/students-occupy-goldsmiths-in-protest-at-institutional-racism

Wilson, S. (2012). They forgot mammy had a brain. In G. Gutiérrez y Muhs, Y. F. Niemann, C. G. González, \& A. Harris (Eds.), Presumed incompetent: The intersections of race and class for women in academia (pp. 65-77). Utah State University Press. 